\title{
Clinical significance of procoagulant microparticles
}

\author{
Shosaku Nomura* and Michiomi Shimizu
}

\begin{abstract}
Microparticles (MPs) are small membrane vesicles that are released from many different cell types by exocytic budding of the plasma membrane in response to cellular activation or apoptosis. MPs may also be involved in clinical diseases because they express phospholipids, which function as procoagulants. Although flow cytometry is the most widely used method for studying MPs, some novel assays, such as tissue factor-dependent procoagulant assay or the ELISA method, have been reported. However, the use of quantification of MP as a clinical tool is still controversial. Elevated platelet-derived MP, endothelial cell-derived MP, and monocyte-derived MP concentrations are documented in almost all thrombotic diseases occurring in venous and arterial beds. However, the significance of MPs in various clinical conditions remains controversial. An example of this controversy is that it is unknown if MPs found in peripheral blood vessels cause thrombosis or whether they are the result of thrombosis. Numerous studies have shown that not only the quantity, but also the cellular origin and composition of circulating MPs, are dependent on the type of disease, the disease state, and medical treatment. Additionally, many different functions have been attributed to MPs. Therefore, the number and type of clinical disorders associated with elevated MPs are currently increasing. However, MPs were initially thought to be small particles with procoagulant activity. Taken together, our review suggests that MPs may be a useful biomarker to identify thrombosis.
\end{abstract}

Keywords: Microparticle, Procoagulant activity, Phospholipid, Thrombosis, Flow cytometry

\section{Introduction}

Microparticles (MPs) are small membrane vesicles that are released from many different cell types by exocytic budding of the plasma membrane in response to cellular activation or apoptosis [1-3]. MPs disseminate various bioactive effectors originating from the parent cells. Therefore, MPs can alter vascular function and may induce biological responses involved in vascular homeostasis [4]. Although most MPs in human blood originate from platelets, MPs are also released from leukocytes, erythrocytes, endothelial cells, smooth muscle cells (SMCs), and cancer cells [5-10]. MP concentrations are documented in almost all thrombotic diseases occurring in venous and arterial beds [11-14]. Elevated levels of MPs have also been found in a number of conditions associated with inflammation, cellular activation and dysfunction, angiogenesis, and transport [15-23]. In this review, we address the function

\footnotetext{
* Correspondence: shosaku-n@mbp.ocn.ne.jp

First Department of Internal Medicine, Kansai Medical University, 2-3-1 Shin-machi, Hirakata, Osaka 573-1191, Japan
}

of MPs and some of the clinical findings that suggest important roles for procoagulant MPs.

\section{Review \\ Composition and production of MPs}

The standard platelet-derived MP (PDMP) measurement by flow cytometry was demonstrated by the International Society of Thrombosis and Haemostasis [24,25]. According to this committee, MPs can range in size from 0.1 to $1.0 \mu \mathrm{m}$. The membrane composition of MPs reflects the membranous elements of the cell of origin (Table 1). PDMPs contain molecules in addition to glycoproteins (GPs), such as platelet-activating factor, $\beta$ amyloid precursor protein, $\mathrm{Ca}^{2+}$-dependent protease calpain, arachidonic acid, and many phospholipids [26-31]. Phospholipids are particularly important because they are involved in the function of PDMPs. Furthermore, PDMPs serve as a finely tuned transcellular delivery system for the chemokine regulated on activation, normal Tcell expressed and secreted (RANTES) [32]. 
Table 1 Origin and antigens of MPs

\begin{tabular}{ll}
\hline Origin & Antigen \\
\hline Erythrocyte & CD235a (glycophorin A) \\
& CD42a (GPIX) \\
& CD42b (GPIb) \\
& CD41 (GPIllb/lla, $\left.a_{\text {IIb }} \beta_{3}\right)$ \\
& CD61 (GPIIla) \\
Leukocyte & CD62P (P-selectin) \\
Neutrocyte & \\
Monocyte & CD66b (CEACAM-1) \\
Lymphocyte & CD14 (endotoxin receptor) \\
Endothelial cell & CD4, CD8, CD20 \\
& CD31 (PECAM-8) \\
& CD51 (vitronectin receptor, $a_{\mathrm{v}} \beta_{3}$ ) \\
& CD54 (ICAM-1) \\
& CD62E (E-selectin) \\
& CD105 (endoglin) \\
& CD144 (VE-cadherin) \\
& CD146 (MelCAM)
\end{tabular}

MPs contain functional cytoadhesions, bioactive phospholipids, cytoplasmic components, and various antigens that are characteristic of the state of the cell from which they originated and also of the type of stimulus [33,34]. Some studies have analyzed the proteome of MPs and identified hundreds of proteins [35,36]. Proteins from
MPs may be useful biomarkers for various disease processes [36].

MPs are constitutively released from the surface of cells, but their formation can be upregulated by cellular activation or apoptosis [37,38]. After cellular activation or apoptosis is triggered, there is a rise in cytosolic calcium concentrations followed by cytoskeletal changes. Many studies have shown that calpain activation is important for PDMP generation [39,40]. Additionally, calpain appears to help limit phosphatidyl inositol phosphate (PIP $)_{2}$ formation following platelet activation, and $\mathrm{PIP}_{2}$ content is an important determinant of PDMP formation [41,42]. However, some reports have suggested the existence of a distinct mechanism of calpain activation $[43,44]$. Plasma membranes of cells contain different types of phospholipids. Although uncharged phospholipids are mainly present in the outer leaflet of the membrane bilayer, the inner leaflet contains negatively charged aminophospholipids, such as phosphatidylserine (PS). During activation or apoptosis of the cell, there is a change in the membrane with alteration in the normal lipid bilayer, 'flip-flopping' the internal PS to the external surface. As a result, PS-exposing MPs may be released from cells (Figure 1) [45].

High shear stress can initiate platelet aggregation and shedding of procoagulant-containing PDMPs [46]. Chow et al. [47] suggested that thrombin that is formed in the vicinity of primary hemostatic plugs in areas of elevated shear stress plays a major role in the propagation of thrombi

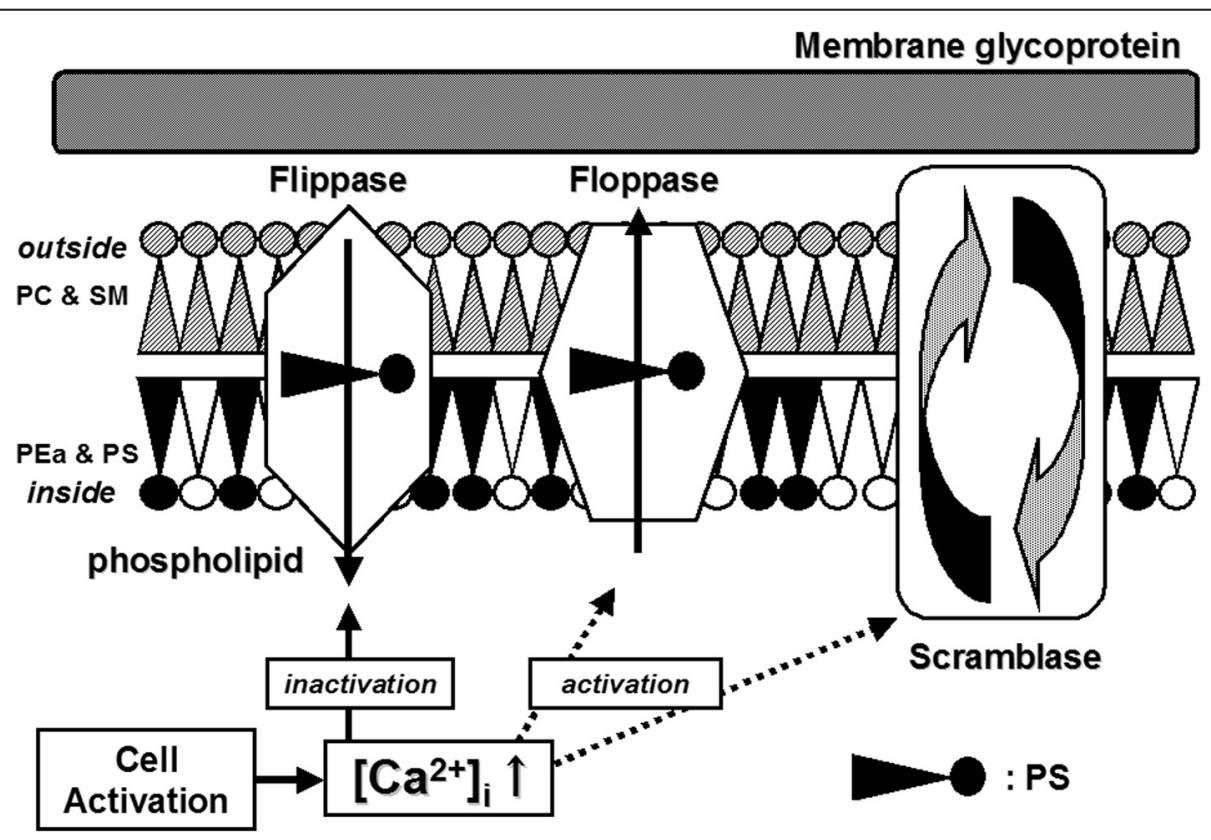

Figure 1 Mechanisms participating in the regulation of transmembrane migration of phosphatidylserine (PS) in activated platelets, followed by PDMP shedding. Phospholipid asymmetry is under the control of active flippase, while floppase and scramblase remain inactive. Following cellular activation, calcium is released from the endoplasmic reticulum, which can lead to the loss of phospholipid asymmetry and activation of calpain. PC, phosphatidylcholine; SM, sphingomyeline; PEa, phosphatidylethanolamine. 
by potentiating shear-induced PDMP generation. Furthermore, platelet GPs and specific receptors can be involved in high shear stress-induced PDMP formation [46,48-50]. Miyazaki et al. [46] examined the mechanisms involved in PDMP production induced by high shear stress and showed that binding of von Willebrand factor to GPIb, influx of extracellular calcium, and activation of platelet calpain were required to generate PDMPs under conditions of high shear stress. In addition, Reininger et al. [50] recently reported that the GPIb receptor mediates adhesion to von Willebrand factor, and under hydrodynamic flow, stretching of the platelet membrane occurs, followed by separation of areas of tethered membranes and production of MPs. Shear stress is also involved in the mechanism of PDMP generation because it is a major determination of endothelial apoptosis $[51,52]$.

MPs are similar to damage-associated molecular patterns (DAMPs). DAMPs are normally hidden within live cells and are released from dying or damaged cells [53]. The typical DAMPs are a high mobility group box 1 (HMGB1)[54]. HMGB1 is normally located in the nucleus where it acts as a DNA chaperon by regulating transcription [55]. However, the extracellular HMGB1 is a substance itself and works tissue injuriously for normal cell or organ [56]. In contrast, the role of MPs is a carrying system of tissue factor (TF), cell adhesion molecules, chemokines, and HMGB1 [56,57]. However, the differences between MPs and DAMPs are actually confused.

\section{Effective roles of MPs for coagulation}

MPs were initially thought to be related to disease because they express phospholipids, which are procoagulants. These MPs support generation of thrombin and could be involved in diffuse intravascular coagulation occurring in disease states. However, such a coagulation system is activated not only in disease states, but also in healthy individuals. Berckmans et al. [58] reported that MPs circulate in healthy humans and support low-grade thrombin generation. Sinauridze et al. [59] reported that PDMPs have 50- to 100-fold higher specific procoagulant activity than activated platelets. Exposure of PS not only facilitates formation of coagulation complexes, but also promotes the ability of TF to initiate coagulation [60].

MPs support coagulation by factor (F)VII/TF-dependent and independent pathways [61]. During vascular damage, blood contacts extravascular TF, resulting in extrinsic coagulation activation and formation of fibrin. Indeed, TF can become active upon adhesion and fusion of MPs to activated platelets.

Several studies found that stimulation by tumor necrosis factor (TNF)- $\alpha$, lipopolysaccharide, or oxidized low-density lipoprotein in cultured human umbilical vein endothelial cells results in an increase in the release of endothelial cell-derived MPs (EDMPs) expressing surface TF $[7,62,63]$. The addition of increasing concentrations of these EDMPs to a coagulation assay shortens the plasma clotting time. This effect is not observed in FVII-deficient plasma, indicating that procoagulant activity of EDMPs is FVII/TF dependent in this situation. Interestingly, a subset of EDMPs bearing von Willebrand factor appears to be able to induce platelet aggregation [64].

Monocyte-derived MPs (MDMPs) also contribute to the development of platelets and fibrin-rich thrombus at sites of vascular injury, through the recruitment of cells and accumulation of TF. MDMPs express the Pselectin glycoprotein ligand-1 and TF [65]. The binding of these MDMPs to P-selectin on activated endothelial cells on activated platelets within the developing thrombus may promote accumulation of TF and localized thrombin generation. TF-exposing monocytes may also release TF-exposing MDMPs [66]. Subsequently, activated platelets expose P-selectin and are capable of capturing TF-exposing MDMPs via P-selectin glycoprotein ligand-1. Consequently, MP-associated TF becomes rapidly deposited at the site of the developing thrombus. DelConde et al. [67] showed in vitro that fusion of membranes of TF-exposing MPs and activated platelets results in the transfer of TF in platelet membranes. This fusion results in co-localization of TF and coagulation factors, thereby promoting a more efficient initiation and propagation of coagulation.

At the MP surface, the presence of proteins inhibiting coagulation, such as TF pathway inhibitor, protein $C$, or thrombomodulin, raises the possibility of eventual contribution of MPs to an anticoagulant pathway $[68,69]$. While TF is exposed by EDMPs, TF activity is markedly inhibited by MP-associated tissue factor pathway inhibitor (TFPI). In storage-induced PDMPs, $10 \%$ of which contain TF, TF-dependent thrombin generation can only be observed in plasma in which TFPI is neutralized [70]. A balance between TF and TFPI at the MP surface is likely to be a crucial feature in the initiation of blood coagulation, and higher levels of MPs containing TF possibly overcome the TFPI anticoagulant pathway [68]. The effect of activated protein $\mathrm{C}$, which has anticoagulant and anti-inflammatory properties, on endothelial cells and EDMP formation has also been studied [69]. Cultured endothelial cells exposed to activated protein $C$ release EDMP with membrane-bound endothelial protein $\mathrm{C}$ receptor. Activated protein $\mathrm{C}$ that is bound to this receptor retains its anticoagulant activity in reducing formation of thrombin [69]. Other mechanisms contributing to the regulation of MP procoagulant properties rely on the balance between TNF- $\alpha$ and anti-inflammatory cytokines, such as interleukin (IL)10. Indeed, endogenous IL-10 was recently reported to downregulate TF expression in monocytes and TFbound MDMP release, impeding generation of thrombin [71]. 


\section{MPs and cellular interactions}

MPs contain antigens of their cell of origin and can transfer these surface molecules to other cell types and organs [72-74]. These carrier vesicles contain material from the lumen of the donor compartment and expose the cytoplasmic side of this compartment at their outer surface, such as exosomes and ectosomes (Figure 2). The binding of MP surface antigens to their specific counter receptor may activate intracellular signaling pathways. PDMPs show transcellular delivery of unmetabolized arachidonic acid. Additionally, PDMP activation of human vascular endothelial cells and U-937 cells induces de novo expression of cyclooxygenase-2 but not cyclooxygenase-1 [30].

The concentrated delivery of PDMP bioactive lipids may modulate multicellular interactions that occur in the early stages of atherogenesis. Nomura et al. [75] also reported that PDMPs that are induced by high shear stress enhance expression of cell adhesion molecules by THP-1 and endothelial cells. PDMPs may contribute to the development of adhesion and participate in vascular damage that is observed in inflammatory disorders. Additionally, PDMPs may possess high mobility and accessibility to leukocytes [76].

\section{Identification of MPs in the clinical setting}

An identification method for MPs is important for clinical studies on MPs. Appropriate sampling conditions, processing, and storage of samples are essential [1]. MPs can be directly quantified in platelet-poor plasma, obtained by serial centrifugation of citrated whole blood. Alternatively,

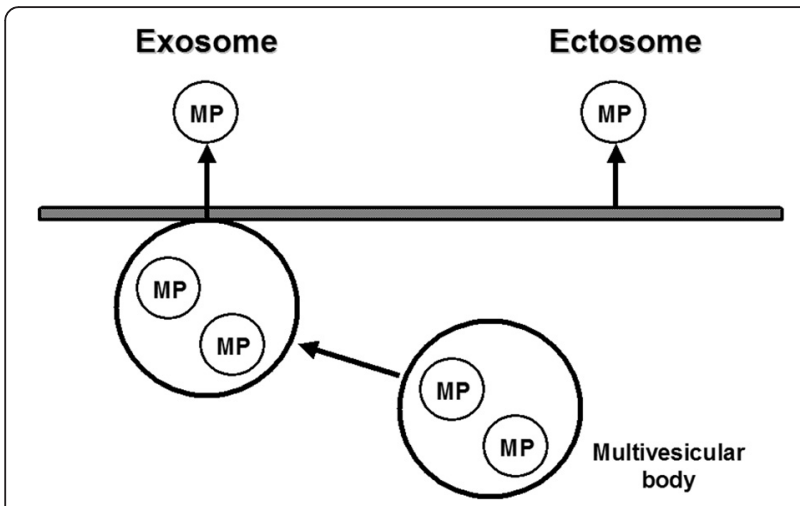

Figure 2 Different types of secreted membrane microparticles. Microparticles or pre-microparticles originally exist in multivesicular bodies. Following cellular activation, multivesicular bodies move close to the cellular membrane. Microparticles that are generated in multivesicular bodies are called exosomes once they are secreted. Secreted vesicles can form inside internal compartments from where they are subsequently secreted by fusion of these compartments with the plasma membrane. This microparticle is called an ectosome Active calpain cleaves the cytoskeleton, leading to the formation of a membrane bleb and ectosome release. Exosome functionates by delivery system of some cellular substances. Ectosome possesses a procoagulant activity. washed MPs can be isolated from platelet-poor plasma by ultracentrifugation before resuspension and analysis.

The most widely used method for studying MPs is flow cytometry because of its simplicity and the wealth of information that can be obtained from the population under study [77]. Platelet-poor plasma or MP suspensions are labeled with fluorescently conjugated monoclonal antibodies. The major advantage of flow cytometry is double staining of MPs to determine the origin/cellular source of MPs. Annexin V binding is used to confirm the phospholipid properties of MPs, although most endothelial MPs do not express this antigen. Antibodies to specific surface antigens expressed on the cells of origin are used to identify the subtype of MP (e.g., antiGPIb for identification of PDMP). Flow cytometry also allows the criterion of size to be applied to MP analysis, by assessment of the forward light scatter of MPs. The identification of events of a specified size is most accurately performed using calibration beads of a known diameter for comparison $[1,26]$. Additionally, a variety of cell-specific antibodies have been used, and the specificity that is chosen is likely to influence the results. An example of this situation is that $\alpha_{\mathrm{IIb}} \beta_{3}$ and P-selectin are both platelet-specific antigens but $\alpha_{\text {IIb }} \beta_{3}$ is present on all platelets, while P-selectin is only found on activated platelets.

The enzyme-linked immunosorbent assay (ELISA) method is an easier and reproducible PDMP assay [78,79]. When using ELISA techniques, PDMPs may be quantitated with reference to a standard curve. This method will hopefully contribute toward the understanding of participation of PDMPs in the clinical setting, if antibodies that are reactive with platelet activation markers, such as Pselectin and soluble CD40 ligand, are used. One of the problems of the ELISA method is the possibility that it contains soluble GPs, such as the GPIb/IX/V complex. Ueba et al. [80-83] measured circulating PDMPs in healthy Japanese individuals using the ELISA method and suggested that PDMPs were positively associated with the level of metabolic syndrome. The use of MP quantification as a clinical tool is still debatable. A large-scale clinical trial for various thrombotic diseases using ELISA kits was performed in Japan [84].

\section{Atherothrombosis and MPs}

Production of PDMPs, EDMPs, and leukocyte-derived MPs can be increased by inflammatory conditions $[85,86]$. MPs formed by in vivo stimulation with a chemotactic peptide in healthy volunteers were able to induce IL-6 and monocyte chemoattractant protein (MCP)-1 release, as well as TF expression, by endothelial cells in vitro. The addition of neutrophils to cultured endothelial cells induces the release of IL-6 and IL-8. This effect can be replicated by cell-free supernatant or purified MPs, but not 
MP-free supernatant [5]. A major feature in atherosclerosis is adhesion of monocytes to endothelial cells, followed by subendothelial transmigration. Cytokines, such as IL$1 \beta$ and TNF- $\alpha$, affect this process by inducing synthesis or upregulation of leukocyte-endothelial adhesion molecules. In vitro stimulation of monocytes and endothelial cells by high shear stress-induced PDMPs results in significantly increased production of Il-8, IL-1 $\beta$, and TNF- $\alpha$ [70]. Furthermore, treatment of endothelial cells and monocytes with PDMPs prior to co-incubation modulates monocyteendothelial cell interactions, by increasing the expression of adhesion molecules on both cell types [70].

Circulating MPs of platelet and leukocytic origins promotes recruitment of inflammatory cells and induces cellular adhesiveness through upregulation of cytokines and cytoadhesions in endothelial cells and monocytes [87]. At high shear stress, PDMP rolling enables delivery of RANTES to inflamed endothelium, thus favoring adhesion of monocytes and infiltration of plaques [32]. Development and progression of atherosclerotic plaques are associated with apoptotic cell death, explaining the presence of a considerable amount of procoagulant MPs within plaques [9]. Furthermore, enhanced apoptosis or activation of leukocytes, SMCs, and endothelium contribute to accumulation of MPs $[9,88]$. Compared with their circulating counterpart, MPs trapped within the plaque are present at much higher concentrations and display higher thrombogenic potential. In plaques, most of these MPs are from activated leukocytes, a hallmark of inflammation, and from erythrocytes, indicating occurrence of intraplaque hemorrhage, which is a marker of vulnerability of plaques [88]. Atherosclerotic plaques also contain a considerable amount of SMC-derived MPs and EDMPs [9]. Beyond the contribution of MPs to plaque thrombogenicity, MPs can also contribute to instability by mediating the recruitment of inflammatory cells. Therefore, circulating MPs can result in vascular inflammation, endothelial dysfunction, leukocyte adhesion, and recruitment. This could contribute to plaque growth or stent-induced vascular inflammation because MPs convey biological effectors [89].

\section{Thrombocytopenia}

Some anti-platelet antibodies can induce complementmediated formation of PDMPs and initiate platelet destruction [90,91]. Antiphospholipid antibodies are found in antiphospholipid antibody syndrome (APS). These antibodies are directed against plasma proteins, including $\beta 2 \mathrm{GPI}$ and prothrombin, which are bound to anionic phospholipids. These phospholipids are abundant on activated platelets, apoptotic cells, and MPs. MP levels are elevated in patients with APS, but not thrombosis, compared with healthy controls [1,92]. Production of procoagulant MPs in APS patients may represent a new pathogenic mechanism for the thrombotic complications of this disease $[7,93]$.
Galli et al. [94] performed a study of PDMPs in thrombotic thrombocytopenic purpura (TTP) and found a rise and fall in PDMP levels with the course of the disease, suggesting that PDMPs are clinically relevant. Jimenez et al. [95] studied the effect of plasma from patients with acute TTP on cultured brain and renal microvascular endothelial cell lines. They found a 5- to 6-fold increase in EDMP generation with TTP plasma compared with controls. Nomura et al. [96] investigated MP levels in patients following allogeneic stem cell transplantation where transplant-related complications included vascular disorders, such as veno-occlusive disease, pulmonary vasculopathy, and thrombotic microangiopathy (TMA). Although only one of the 21 patients who were studied developed TMA/TTP, a continuous rise in platelets, EDMPs, and MDMPs was observed in all of the patients, for up to 4 weeks following transplantation. These findings paralleled an increase in soluble endothelial markers, including vascular cell adhesion molecule (VCAM)-1 and E-selectin.

\section{Cardiovascular diseases}

Procoagulant MPs, and especially EDMP, are elevated in patients with acute coronary syndrome compared with patients with stable anginal symptoms or controls [97]. This finding reflects the degree of acute vascular injury and inflammation at the time of measurement. Steppich et al. [63] reported that in acute myocardial infarction, MPs may also have an anticoagulant function through expression of TFPI and reduction of TF-dependent thrombin generation, which may help limit thrombus formation. Furthermore, EDMP levels are higher in high-risk coronary lesions compared with low-risk lesions [98].

A number of cytokines can induce procoagulant activity in leukocytes [99]. A proinflammatory member of the C-C chemokine family, RANTES, is a potent chemoattractant of memory $\mathrm{T}$ lymphocytes, monocytes, eosinophils, and basophils. Several previous studies have suggested that RANTES is an inflammatory mediator in cardiovascular disease $[11,85,100]$. Additionally, the presence of RANTES may predict restenosis after percutaneous coronary intervention in patients with stable angina [101,102]. PDMPs also relate to the levels of RANTES [11,32,79] and are associated with atherosclerotic events after percutaneous coronary intervention [103].

\section{Diabetes mellitus}

A few studies on the potential role of PDMPs in diabetic complications have been reported [104-106]. MPs are elevated in diabetic patients. However, studies have found differences in the MP profile in relation to the disease type and the presence or absence of MPs. Sabatier et al. [107] reported that in type 1 diabetes, the procoagulant potential of MPs, as measured by a prothrombinase assay, was elevated and correlated with the degree of glycemic 
control. In contrast to type 1 diabetes, they found that although total numbers of MPs were elevated in type 2 diabetes, there was no associated increase in their procoagulant potential. Levels of PDMPs and MDMPs are correlated with diabetic complications or the extent of diabetic retinopathy, which is associated with microvascular damage [108-114]. Elevated EDMP levels are predictive for the presence of coronary artery lesions, and they are a more significant independent risk factor than the length of diabetic disease, lipid levels, or presence of hypertension [115]. Interestingly, elevated EDMP levels are predictive in identifying a subpopulation of diabetic patients without typical anginal symptoms who have angiographic evidence of coronary artery disease. Production of PDMP, MDMP, and EDMP can be increased in type 2 diabetes. These MPs contribute to the generation of atherothrombosis in type 2 diabetes (Figure 3 ).

\section{Sepsis and disseminated intravascular coagulation}

Disseminated intravascular coagulation (DIC) is frequently complicated by various diseases [116]. Coagulation abnormalities and thrombocytopenia are common in DIC, and the extent of hemostatic disorders appears to correlate with disease severity. In particular, septic shock-induced DIC contributes to multiple organ failure. In DIC patients, thrombin generation may react with thrombin receptors located on platelets and results in the generation of PDMPs by activation of platelets. Additionally, HMGB1 also plays a role in the pathogenesis of DIC because plasma HMGB1 levels correlate with the DIC score [117]. Nomura et al. [118] described the role of PDMPs and HMGB1 in DIC patients with hematological malignancies.

Activation of leukocytes and endothelial cells are also observed in DIC. These contribute to the generation of EDMPs, MDMPs, and others. Delabranche et al. [119] reported that EDMPs are relevant biomarkers of septic shock-induced DIC and can be used to evaluate early vascular injury. Furthermore, Hellum et al. [120] recently reported that MPs that were obtained from patients with meningococcal septic shock displayed more efficient TF-dependent thrombin generation and clot

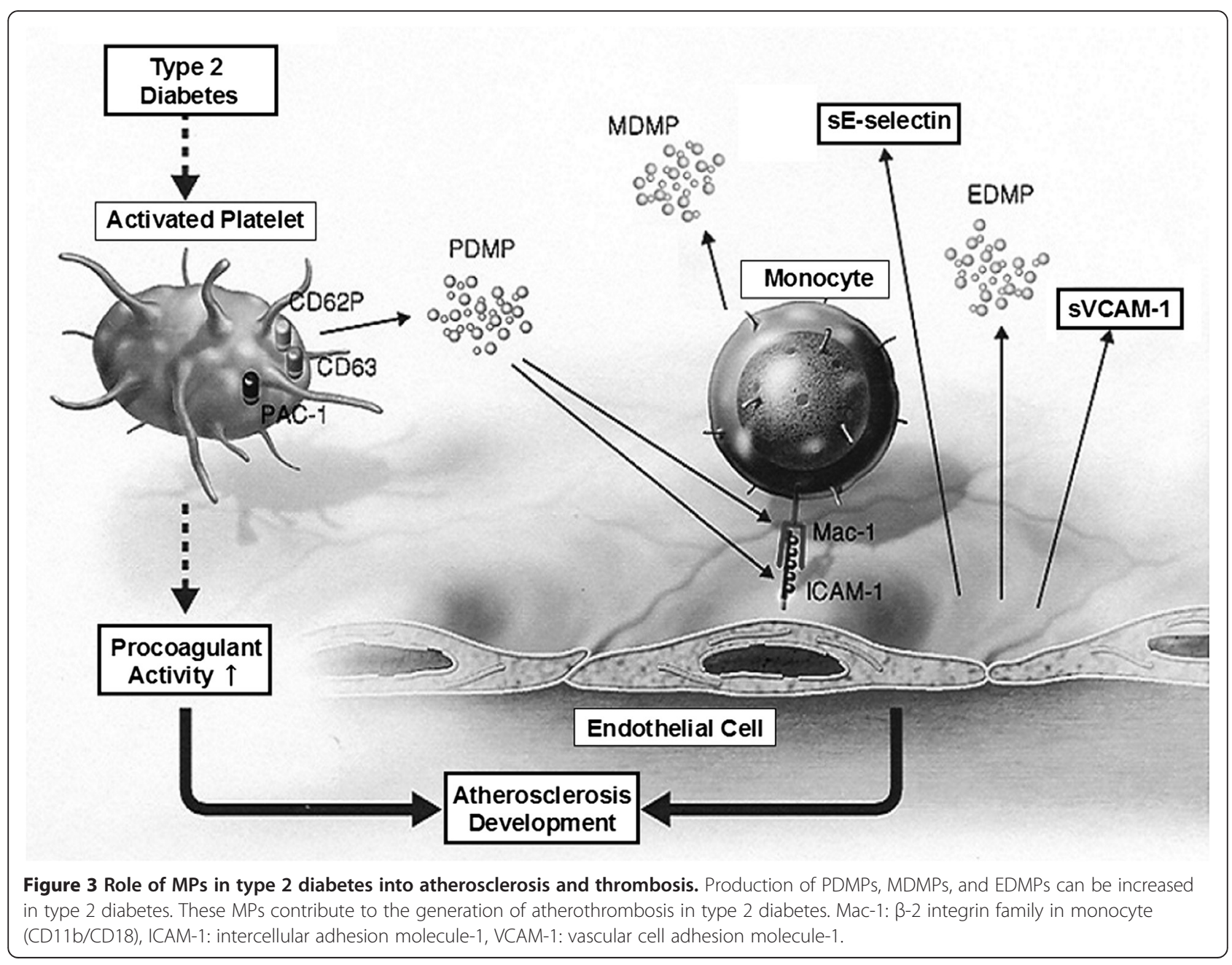


formation compared with MPs from meningitis patients. They concluded that MP-associated TF activity was closely associated with plasma lipopolysaccharide levels in the septic shock group. These changes are thought to be dependent on TF on MPs (Figure 4).

\section{Other clinical situations}

Elevated PDMP levels have been detected in other clinical conditions, including infectious diseases [121,122], peripheral blood stem cell harvest [123-125], progressive systemic sclerosis [126], and arteriosclerosis obliterans [127,128]. Additionally, PDMPs are used for monitoring of antithrombotic therapy $[110,129]$.

PDMPs bind to hematopoietic cells, resulting in enhancement of their engraftment by stimulating proliferation, survival, adhesion, and chemotaxis [130-132]. Majka et al. [133] also reported that PDMPs transfer plateletspecific immunoreactive antigens to the surface of endothelial and hematopoietic cells. Another study showed that endothelial progenitor cell-derived MPs were incorporated in endothelial cells by interaction with $\alpha 4$ and $\beta 1$ integrins expressed on the MP surface [134]. This finding suggested that endothelial progenitor cells may activate angiogenesis in endothelial cells by releasing MPs able to trigger an angiogenic program. CD42b-negative/ $\alpha 4$-integrin-positive MPs show the same changes as stroma cell-derived factor 1 and soluble CD40 ligand, with an increase in CD34 ${ }^{+}$ stem cells during peripheral blood stem cell harvest [118]. Janowska-Wieczorek et al. [135] suggested that MPs that are actively released from cells may play an important role in cell-to-cell communication. Results from other studies have also supported this view [124,134,136]. Furthermore, elevation of EDMPs in patients following allogeneic stem cell transplantation may be associated with some transplantrelated complications, such as graft-versus-host-disease (GVHD) and TMA [96,125,131].

In lung cancer patients, PDMPs induce metastasis and angiogenesis, [135] and MDMPs may be a sign of vascular

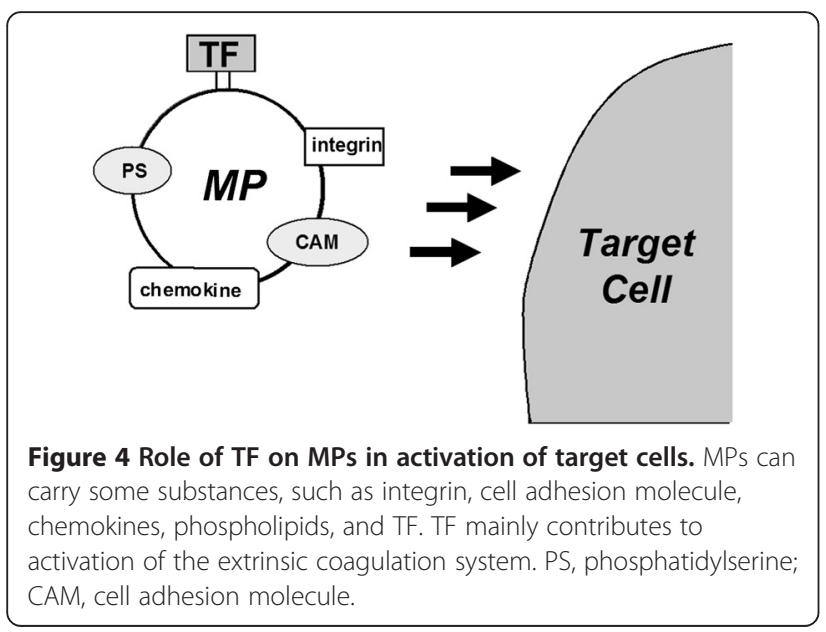

complications [137]. In patients with various types of cancer, PDMPs possess CXCR4 and contribute to chemotaxis by stromal cell-derived factor 1 , resulting in progression or metastasis of cancer $[138,139]$. TF overexpression by cancer cells is closely associated with tumor progression, and TF-expressing MPs that are shed by cancer cells are linked to the genetic status of cancer [140-144].

A current feature of clinical applications regarding MPs is detection of TF-expressing MPs that are generated by apoptosis. Fas ligand- or TNF-related apoptosisinducing ligand-positive MPs have been isolated from sera of patients with cancer, and these MPs can induce T-cell apoptosis [145-147]. The pattern of procoagulant MPs that are released during acute allograft rejection suggests endothelial cell activation and Fas-mediated apoptosis [148]. Procoagulant MPs in pulmonary arterial hypertension also belong to apoptotic EDMPs [149].

\section{Conclusion}

We have summarized the literature to date that is relevant to MPs, including a growing list of clinical disorders that are associated with elevated MP levels. MPs were initially thought to be small particles with procoagulant activity. However, the possibility that MPs evoke cellular responses in the immediate microenvironments where they are formed is now under investigation.

\section{Abbreviations}

APS: antiphospholipid antibody syndrome; CXCR4: CXC receptor 4, CD184; DAMPs: damage-associated molecular patterns; DIC: disseminated intravascular coagulation; EDMP: endothelial cell-derived microparticle; ELISA: enzyme-linked immunosorbent assay; FVII: factor VII; GP: glycoprotein; GVHD: graft-versus-host disease; HMGB1: high-mobility group-B1 DNAbinding protein 1; IL-6: interleukin-6; IL-10: interleukin-10; MCP-1: monocyte chemoattractant protein-1; MDMP: monocyte-derived microparticle; MP: microparticle; PDMP: platelet-derived microparticle; PIP 2 : phosphatidyl inositol phosphate 2; PS: phosphatidylserine; RANTES: regulated on activation, normal T-cell expressed and secreted; SMC: smooth muscle cell; TF: tissue factor; TFPI: tissue factor pathway inhibitor; TMA: thrombotic microangiopathy; TNF-a: tumor necrosis factor-a; TTP: thrombotic thrombocytopenic purpura; VCAM-1: vascular cell adhesion molecule-1.

\section{Competing interests}

None of the authors disclose any financial of personal relationships with other people or organizations that could inappropriately influence (bias) their work. Examples of potential conflicts of interest include employment, consultancies, stock ownership, honoraria, paid expert testimony, patent applications/registrations, and grants or other funding.

\section{Authors' contributions}

SN mainly contributed to write this paper. MS mainly contributed to review references. All of the authors discussed for this review. Both authors read and approved the final manuscript.

\section{Acknowledgements}

This study was supported in part by research grants from the Japanese Ministry of Health, Labour and Welfare and the Japanese Ministry of Education, Science, Sports and Culture. 


\section{References}

1. Jy W, Horstman LL, Jimenez JJ, Ahn YS, Biró E, Nieuwland R, et al. Measurement circulating cell-derived microparticles. J Thromb Haemost. 2004:2:1842-51

2. Nomura S, Ozaki Y, Ikeda Y. Function and role of microparticles in various clinical settings. Thromb Res. 2008;123:8-23.

3. Burnier L, Fontana P, Kwak BR, Angelillo-Scherrer A. Cell-derived microparticles in haemostasis and vascular medicine. Thromb Haemost. 2009;101:439-51.

4. Morel O, Toti F, Hugel B, Bakouboula B, Camoin-Jau L, Dignat-George F، et al. Procoagulant microparticles: disrupting the vascular homeostasis equation? Arterioscler Thromb Vasc Biol. 2006;26:2594-604.

5. Mesri M, Altieri DC. Endothelial cell activation by leukocyte microparticles. J Immunol. 1998;161:4382-7.

6. Hugel B, Socie G, Vu T, Toti F, Gluckman E, Freyssinet JM, et al. Elevated levels of circulating procoagulant microparticles in patients with paroxysmal nocturnal hemoglobinuria and aplastic anemia. Blood. 1999;93:3451-6.

7. Combes V, Simon AC, Grau GE, Arnoux D, Camoin L, Sabatier F, et al. In vitro generation of endothelial microparticles and possible prothrombotic activity in patients with lupus anticoagulant. J Clin Invest. 1999;104:93-102.

8. Sabatier F, Roux V, Anfosso F, Camoin L, Sampol J, Dignat-George F. Interaction of endothelial microparticles with monocytic cells in vitro induces tissue factordependent procoagulant activity. Blood. 2002:99:3962-70.

9. Angelillo-Scherrer A. Leukocyte-derived microparticles in vascular homeostasis. Circ Res. 2012;110:356-69.

10. Zwicker Jl, Liebman HA, Neuberg D, Lacroix R, Bauer KA, Furie BC, et al. Tumorderived tissue factor-bearing microparticles are associated with venous thromboembolic events in malignancy. Clin Cancer Res. 2009;15:6830-40.

11. Matsumoto N, Nomura S, Kamihata H, Kimura Y, Iwasaka T. Increased level of oxidized LDL-dependent monocyte-derived microparticles in acute coronary syndrome. Thromb Haemost. 2004;91:146-54.

12. Chirinos JA, Heresi GA, Velasquez $H$, Jy W, Jimenez JJ, Ahn $E$, et al. Elevation of endothelial microparticles, platelets, and leukocyte activation in patients with venous thromboembolism. J Am Coll Cardiol. 2005:45:1467-71.

13. Simak J, Gelderman MP, Yu H, Wright V, Baird AE. Circulating endothelial microparticles in acute ischemic stroke: a link to severity, lesion volume and outcome. J Thromb Haemost. 2006;4:1296-302.

14. Ederhy S, Di Angelantonio E, Mallat Z, Hugel B, Janower S, Meuleman C, et al. Levels of circulating procoagulant microparticles in nonvalvular atrial fibrillation. Am J Cardiol. 2007:100:989-94.

15. Mack M, Kleinschmidt A, Brühl H, Klier C, Nelson PJ, Cihak J, et al. Transfer of the chemokine receptor CCR5 between cells by membrane-derived microparticles: a mechanism for cellular human immunodeficiency virus 1 infection. Nat Med. 2000;6:769-75.

16. Boulanger CM, Scoazec A, Ebrahimian T, Henry P, Mathieu E, Tedgui A, et al. Circulating microparticles from patients with myocardial infarction cause endothelial dysfunction. Circulation. 2001;104:2649-52.

17. Kim HK, Song KS, Chung JH, Lee KR, Lee SN. Platelet microparticles induce angiogenesis in vitro. Br J Haematol. 2004;124:376-84

18. Biró E, Nieuwland R, Tak PP, Pronk LM, Schaap MC, Sturk A, et al. Activated complement components and complement activator molecules on the surface of cell-derived microparticles in patients with rheumatoid arthritis and healthy individuals. Ann Rheum Dis. 2007;66:1085-92.

19. Manly DA, Wang J, Glover SL, Kasthuri R, Liebman HA, Key NS, et al. Increased microparticle tissue factor activity in cancer patients with venous thromboembolism. Thromb Res. 2010;125:511-2.

20. Sinning JM, Losch J, Walenta K, Böhm M, Nickenig G, Werner N. Circulating $\mathrm{CD} 1^{+}$/annexin $\mathrm{V}^{+}$microparticles correlate with cardiovascular outcomes. Eur Heart J. 2010;32:2034-41.

21. Wang JG, Geddings JE, Aleman MM, Cardenas JC, Chantrathammachart P, Williams $\mathrm{JC}$, et al. Tumor-derived tissue factor activates coagulation and enhances thrombosis in a mouse xenograft model of human pancreatic cancer. Blood. 2012;119:5543-52

22. Suades R, Padró T, Alonso R, Mata P, Badimon L. Lipid-lowering therapy with statins reduces microparticles shedding from endothelium, platelets and inflammatory cells. Thromb Haemost. 2013;110:366-77.

23. Suades R, Padró T, Alonso R, López-Miranda J, Mata P, Badimon L. Circulating $\mathrm{CD} 45^{+} / \mathrm{CD}^{+}$lymphocyte-derived microparticles map lipid-rich atherosclerotic plaques in FH patients. Thromb Haemost. 2014;111:111-21.

24. Lacroix R, Robert S, Poncelet P, Kasthuri RS, Key NS, Dignat-George F. Standardization of platelet-derived microparticle enumeration by flow cytometry with calibrated beads: results of the International Society on Thrombosis and Haemostasis SSC Collaborative workshop. J Thromb Haemost. 2010;8:2571-4

25. Lacroix R, Judicone C, Mooberry M, Boucekine M, Key NS, Dignat-George F. Standardization of preanalytical variables in plasma microparticle determination: results of the International Society on Thrombosis and Haemostasis SSC Collaborative workshop. J Thromb Haemost. 2013;11:1190-3.

26. Nomura S, Nakamura T, Cone J, Tandon NN, Kambayashi J. Cytometric analysis of high shear-induced platelet microparticles and effect of cytokines on microparticle generation. Cytometry. 2000;40:173-81.

27. Iwamoto S, Kawasaki T, Kambayashi J, Ariyoshi H, Monden M. Platelet microparticles: a carrier of platelet-activating factor ? Biochem Biophys Res Commun. 1996;218:940-4.

28. Nomura S, Komiyama Y, Miyake T, Miyazaki Y, Kido H, Suzuki M, et al. Amyloid $\beta$-protein precursor-rich platelet microparticles in thrombotic disease. Thromb Haemost. 1994;72:519-22.

29. Pasquet J-M, Toti F, Nurden AT, Dachery-Prigent J. Procoagulant activity and active calpain in platelet-derived microparticles. Thromb Res. 1996;82:509-22.

30. Barry OP, Kazanietz MG, Pratico D, FitzGerald GA. Arachidonic acid in platelet microparticles upregulates cyclooxygenase-2 dependent prostaglandin formation via a protein kinase C/mitogen-activated protein kinase-dependent pathway. J Biol Chem. 1999;274:7545-56.

31. Zwaal RFA, Comfurius P, Bevers EM. Platelet procoagulant activity and microvesicle formation: its putative role in hemostasis and thrombosis Biochim Biophys Acta. 1992;1180:1-8.

32. Mause SF, von Hundelshausen P, Zernecke A, Koenen RR, Weber C. Platelet microparticles: a transcellular delivery system for RANTES promoting monocyte recruitment on endothelium. Arterioscler Thromb Vasc Biol. 2005;25:1512-8.

33. Freyssinet JM. Cellular microparticles: What are they bad or good for ? J Thromb Haemost. 2003;1:1655-62

34. Abid Hussein MN, Meesters EW, Osmanovic N, Romijn FP, Nieuwland R, Sturk A. Antigenic characterization of endothelial cell-derived microparticles and their detection ex vivo. J Thromb Haemost. 2003;1:2434-43.

35. Garcia BA, Smalley DM, Cho H, Shabanowitz J, Ley K, Hunt DF. The platelet microparticle proteome. J Proteome Res. 2005;4:1516-21.

36. Smalley DM, Root KE, Cho H, Ross MM, Ley K. Proteomic discovery of 21 proteins expressed in human plasma-derived but not platelet-derived microparticles. Thromb Haemost. 2007;97:67-80.

37. Lynch SF, Ludlam CA. Plasma microparticles and vascular disorders. Br J Haematol. 2007;137:36-48.

38. Sabatier F, Camoin-Jau L, Anfosso F, Sampol J, Dignat-George F. Circulating endothelial cells, microparticles and progenitors: key players towards the definition of vascular competence. J Cell Mol Med. 2009;13:454-71.

39. Pasquet J-M, Dachary-Prigent J, Nurden AT. Microvesicle release is associated with extensive protein tyrosine dephosphorylation in platelets stimulated by A23187 or a mixture of thrombin and collagen. Biochem J. 1998;333:591-9.

40. Rendu F, Brohard-Bohn B, Pain S, Bachelot-Loza C, Auger J. Thiosulfinates inhibit platelet aggregation and microparticle shedding at a calpaindependent step. Thromb Haemost. 2001;86:1284-91.

41. O'Connell DJ, Rozenvayn N, Flaumenhaft R. Phosphatidylinositol 4,5bisphosphate regulates activation-induced platelet microparticle formation. Biochemistry. 2005:44:6361-70.

42. Flaumenhaft R. Formation and fate of platelet microparticles. Blood Cells Mol Dis. 2006:36:182-7

43. Cauwenberghs S, Feijge MA, Harper AG, Sage SO, Curvers J, Heemskerk JW Shedding of procoagulant microparticles from unstimulated platelets by integrin-mediated destabilization of actin cytoskeleton. FEBS Lett. 2006:580:5313-20.

44. Ray DM, Spinelli SL, Pollock SJ, Murant TI, O'Brien JJ, Blumberg N, et al. Peroxisome proliferator-activated receptor gamma and retinoid $\mathrm{X}$ receptor transcription factors are released from activated human platelets and shed in microparticles. Thromb Haemost. 2008;99:86-95.

45. Kaplan ZS, Jackson SP. The role of platelets in atherothrombosis Hematology Am Soc Hematol Educ Program. 2011;2011:51-61.

46. Miyazaki Y, Nomura S, Miyake T, Kagawa H, Kitada C, Taniguchi H, et al. High shear stress can initiate both platelet aggregation and shedding of procoagulant containing microparticles. Blood. 1996:88:3456-64.

47. Chow TW, Hellums JD, Thiagarajan P. Thrombin receptor activating peptide (SFLLRN) potentiates shear-induced platelet microvesiculation. J Lab Clin Med. 2000;135:66-72. 
48. Goto S, Tamura N, Eto K, Ikeda Y, Handa S. Functional significance of adenosine 5'-diphosphate receptor (P2Y (12)) inplatelet activation initiated by binding of von Willebrand factor to platelet GPIba induced by conditions of high shear rate. Circulation. 2002:105:2531-6.

49. Pontiggia L, Steiner B, Ulrichts H, Deckmyn H, Forestier M, Beer JH. Platelet microparticle formation and thrombin generation under high shear are effectively suppressed by a monoclonal antibody against GPIba. Thromb Haemost. 2006:96:774-80.

50. Reininger AJ, Heijnen HF, Schumann H, Specht HM, Schramm W, Ruggeri ZM. Mechanism of platelet adhesion to von Willebrand factor and microparticle formation under high shear stress. Blood. 2006;107:3537-45.

51. Sapet C, Simoncini S, Loriod B, Puthier D, Sampol J, Nguyen C, et al. Thrombin-induced endothelial microparticle generation: identification of a novel pathway involving ROCK-II activation by caspase-2. Blood. 2006:108:1868-76.

52. Boulanger CM, Amabile N, Guerin AP, Pannier B, Leroyer AS, Mallat CN, et al. In vivo shear stress determines circulating levels of endothelial microparticles in end-stage renal disease. Hypertension. 2007;49:902-8.

53. Garg AD, Nowis D, Golab J, Vandenabeele P, Krysko DV, Agostinis P. Immunogenic cell death, DAMPs and anticancer therapeutics: an emerging amalgamation. Biochim Biophys Acta. 2010;1805:53-71.

54. Weir HM, Kraulis PJ, Hill CS, Raine AR, Laue ED, Thomas JO. Structure of the HMG box motif in the B-domain of HMG1. EMBO J. 1993;12:1311-9.

55. Tang D, Kang R, Zej 3rd HJ, Lotze MT. High-mobility group box 1 and cancer. Biochim Biophys Acta. 2010;1799:131-40.

56. Magna M, Pisetsky DS. The role of HMGB1 in the pathogenesis of inflammatory and autoimmune disease. Mol Med. 2014:20:138-46.

57. Pisetsky DS. The expression of HMGB1 on microparticles released during cell activation and cell death in vitro and in vivo. Mol Med. 2014;20:158-63.

58. Berckmans RJ, Nieuwland R, Boing AN, Romijn FP, Hack CE, Sturk A. Cellderived microparticles circulate in healthy humans and support low grade thrombin generation. Thromb Haemost. 2001:85:639-46.

59. Sinauridze El, Kireev DA, Popenko NY, Pichugin AV, Panteleev MA, Krymskaya OV, et al. Platelet microparticle membranes have 50- to 100-fold higher specific procoagulant activity than activated platelets. Thromb Haemost. 2007:97:425-34.

60. Wolberg AS, Monroe DM, Roberts HR, Hoffman MR. Tissue factor deencryption: ionophore treatment induces changes in tissue factor activity by phosphatidylserine-dependent and -independent mechanisms. Blood Coagul Fibrinolysis. 1999;10:201-10.

61. Khan MM, Hattori T, Niewiarowski S, Edmunds Jr LH, Colman RW. Truncated and microparticle-free soluble tissue factor bound to peripheral monocytes preferentially activated factor VII. Thromb Haemost. 2006;95:462-8.

62. Kagawa H, Komiyama Y, Nakamura S, Miyake T, Miyazaki Y, Hamamoto K, et al. Expression of functional tissue factor on small vesicles of lipopolysaccharidestimulated human vascular endothelial cells. Thromb Res. 1998;91:297-304.

63. Nomura S, Shouzu A, Omoto S, Nishikawa M, Iwasaka T, Fukuhara S. Activated platelets and oxidized LDL induce endothelial membrane vesiculation: clinical significance of endothelial cell-derived microparticles in patients with type 2 diabetes. Clin Appl Thromb Hemost. 2004;10:205-15.

64. Jy W, Jimenez JJ, Mauro LM, Hoestman LL, Cheng P, Ahn ER, et al. Endothelial microparticles induce formation of platelet aggregates via a von Willebrand factor/ristocetin dependent pathway, rendering them resistant to dissociation. J Thromb Haemost. 2005;3:1301-8.

65. Falati S, Liu Q, Gross P, Merrill-Skoloff G, Chou J, Vandendries E, et al. Accumulation of tissue factor into developing thrombi in vivo is dependent upon microparticle P-selectin glycoprotein ligand 1 and platelet P-selectin. J Exp Med. 2003;197:1585-98

66. Losche W. Platelets and tissue factor. Platelets. 2005;16:313-9.

67. Del Conde I, Shrimpton CN, Thiagarajan P, López JA. Tissue-factor- bearing microvesicles arise from lipid rafts and fuse with activated platelets to initiate coagulation. Blood. 2005;106:1604-11.

68. Steppich B, Mattisek C, Sobczyk D, Kastrati A, Schömig A, Ott I. Tissue factor pathway inhibitor on circulating microparticles in acute myocardial infarction. Thromb Haemost. 2005;93:35-9.

69. Perez-Casal M, Downey C, Fukudome K, Marx G, Toh CH. Activated protein $C$ induces the release of microparticle-associated endothelial protein $C$ receptor. Blood. 2005;105:1515-22.

70. Keuren JF, Magdeleyns EJ, Govers-Riemslag JW, Lindhout T, Cuvers J. Effects of storage-induced platelet microparticles on the initiation and propagation phase of blood coagulation. Br J Haematol. 2006;134:307-13.
71. Poitevin S, Cochery-Nouvellon E, Dupont A, Nguven P. Monocyte IL-10 produced in response to lipopolysaccharide modulates thrombin generation by inhibiting tissue factor expression and release of active tissue factor-bound microparticles. Thromb Haemost. 2007:97:598-607.

72. Théry C, Ostrowski M, Segura E. Membrane vesicles as conveyors of immune responses. Nat Rev Immunol. 2009;9:581-93.

73. Robbins PD, Morelli AE. Regulation of immune responses by extracellular vesicles. Nat Rev Immunol. 2014;14:195-208.

74. Geddings JE, Mackman N. New players in haemostasis and thrombosis. Thromb Haemost. 2014:111:570-4.

75. Nomura S, Tandon NN, Nakamura T, Cone J, Fukuhara S, Kambayashi J. High-shear-stress-induced activation of platelets and microparticles enhances expression of cell adhesion molecules in THP-1 and endothelial cells. Atherosclerosis. 2001;158:277-87.

76. Nomura $\mathrm{S}$, Inami $\mathrm{N}$, Iwasaka T. Differences in functional roles between activated platelets and platelet-derived microparticles. Thromb Haemost. 2007:98:1143-4.

77. Shantsila E, Montoro-Garcia S, Gallego P, Lip GYH. Circulating microparticles: challenges and perspectives of flow cytometric assessment. Thromb Haemost. 2014;111:1009-14.

78. Osumi K, Ozeki Y, Saito S, Nagamura Y, Ito H, Kimura Y, et al. Development and assessment of enzyme immunoassay for platelet-derived microparticles. Thromb Haemost. 2001:85:326-30.

79. Nomura S, Uehata S, Saito S, Osumi K, Ozeki Y, Kimura Y. Enzyme immunoassay detection of platelet-derived microparticles and RANTES in acute coronary syndrome. Thromb Haemost. 2003;89:506-12.

80. Ueba T, Haze T, Sugiyama M, Higuchi M, Asayama H, Karitani Y, et al. Level, distribution and correlates of platelet-derived microparticles in healthy Japanese people with special reference to the metabolic syndrome. Thromb Haemost. 2008:100:280-5.

81. Ueba T, Nomura S, Inami N, Nishikawa T, Kajiwara M, Iwata R, et al. Correlation and association of plasma interleukin- 6 and plasma plateletderived microparticles, markers of activated platelets, in healthy individuals. Thromb Res. 2010;125:e329-34.

82. Ueba T, Nomura S, Inami N, Nishikawa T, Kajiwara M, Iwata R, et al. Plasma level of platelet-derived microparticles is associated with coronary heart disease risk score in healthy men. J Atheroscler Thromb. 2010;17:342-9.

83. Ueba T, Nomura S, Inami N, Yokoi T, Inoue T. Elevated RANTES levels associated with metabolic syndrome and correlated with activated platelets associated markers in healthy younger men. Clin Appl Thromb Hemost. 2014;20:813-8.

84. Nomura S, Shouzu A, Taomoto K, Togane Y, Goto S, Ozaki Y, et al. Assessment of an ELISA kit for platelet-derived microparticles by joint research at many institutes in Japan. J Atheroscler Thromb. 2009;16:878-87.

85. Joop K, Berckmans RJ, Nieuwland R, Berkhout J, Romijin FP, Hack CE, et al. Microparticles from patients with multiple organ dysfunction syndrome and sepsis support coagulation through multiple mechanisms. Thromb Haemost. 2001;85:810-20

86. Daniel L, Fakhouri F, Joly D, Mouthon L, Nusbaum P, Grunfeld JP, et al. Increase of circulating neutrophil and platelet microparticles during acute vasculitis and hemodialysis. Kidney Int. 2006;69:1416-23.

87. Barry OP, FitzGerald GA. Mechanisms of cellular activation by platelet microparticles. Thromb Haemost. 1999:82:794-800.

88. Leroyer AS, Isobe H, Lesèche G, Castier Y, Wassef M, Mallat Z, et al. Cellular origins and thrombogenic activity of microparticles isolated from human atherosclerotic plaques. J Am Coll Cardiol. 2007;49:772-7.

89. Chironi G, Simon A, Hugel B, Del Pino M, Gariepy J, Freyssinet JM, et al. Circulating leukocyte-derived microparticles predict subclinical atherosclerosis in asymptomatic subjects. Arterioscler Thromb Vasc Biol. 2006:26:2775-80

90. Naghama M, Nomura S, Ozaki Y, Yoshimura C, Kagawa H, Fukuhara S. Platelet activation markers and soluble adhesion molecules in patients with systemic lupus erythematosus. Autoimmunity. 2001;33:85-94.

91. Pereira J, Alfaro G, Goycoolea M, Quiroga T, Ocqueteau M, Massardo L, et al. Circulating platelet-derived microparticles in systemic lupus erythematosus. Association with increased thrombin generation and procoagulant state. Thromb Haemost. 2006;95:94-9.

92. Nagahama M, Nomura S, Kanazawa S, Ozaki Y, Kagawa H, Fukuhara S. Significance of anti-oxidized LDL antibody and monocyte-derived microparticles in anti-phospholipid antibody syndrome. Autoimmunity. 2003;36:125-31. 
93. Dignat-George F, Camoin-Jau L, Sabatier F, Arnoux D, Anfosso F, Bardin N, et al. Endothelial microparticles: a potential contribution to the thrombotic complications of the antiphospholipid syndrome. Thromb Haemost. 2004:91:667-73.

94. Galli M, Grassi A, Barbui T. Platelet-derived microparticles in thrombotic thrombocytopenic purpura and hemolytic uremic syndrome. Thromb Haemost. 1996;75:427-31.

95. Jimenez JJ, Jy W, Mauro LM, Horstman LL, Ahn YS. Elevated endothelial microparticles in thrombotic thrombocytopenic purpura: findings from brain and renal microvascular cell culture and patients with active disease. Br J Haematol. 2001;112:81-90.

96. Nomura S, Ishii K, Kanazawa S, Inami N, Uoshima N, Ishida H, et al. Significance of elevation in cell-derived microparticles after allogeneic stem cell transplantation: transient elevation of platelet-derived microparticles in TMA/TTP. Bone Marrow Transplant. 2005;36:921-2.

97. Bernal-Mizrachi L, Jy W, Jimenez JJ, Pastor J, Mauro LM, Horstman LL, et al. High levels of circulating endothelial microparticles in patients with acute coronary syndromes. Am Heart J. 2003;145:962-70.

98. Bernal-Mizrachi L, Jy W, Fierro C, Macdonough R, Velazques HA, Purow J, et al. Endothelial microparticles correlate with high-risk angiographic lesions in acute coronary syndromes. Int J Cardiol. 2004;97:439-46.

99. Neuwmann FJ, Ott I, Marx N, Luther T, Kenngott S, Gawaz M, et al. Effect of human recombinant interleukin-6 and interleukin-8 on monocyte procoagulant activity. Arterioscler Thromb Vasc Biol. 1997;17:3399-405.

100. Steppich BA, Moog P, Matissek C, Winiowski N, Kuhle J, Joghetaei N, et al. Cytokine profiles and $\mathrm{T}$ cell function in acute coronary syndrome. Atherosclerosis. 2007;190:443-51.

101. Inami N, Nomura S, Manabe K, Kumura Y, Iwasaka T. Platelet-derived chemokine RANTES may be a sign of restenosis after percutaneous coronary intervention in patients with stable angina pectoris. Platelets. 2006;17:565-70.

102. Inami N, Nomura S, Shimazu T, Manabe K, Kumura Y, Iwasaka T. Adiponectin incompletely prevent MCP-1-dependent restenosis after percutaneous coronary intervention in patients with coronary artery disease. J Thromb Thrombolysis. 2007;24:267-73.

103. Namba M, Tanaka A, Shimada K, Ozaki Y, Uehata S, Sakamoto T, et al. Circulating platelet-derived microparticles are associated with atherothrombotic events. A marker for vulnerable blood. Arterioscler Thromb Vasc Biol. 2007;27:255-6.

104. Nomura S, Shouzu A, Omoto S, Nishikawa M, Fukuhara S. Significance of chemokines and activated platelets in patients with diabetes. Clin Exp Immunol. 2000;121:437-43.

105. Nomura S, Kanazawa S, Fukuhara S. Effects of eicosapentaenoic acid on platelet activation markers and cell adhesion molecules in hyperlipidemic patients with type 2 diabetes mellitus. J Diabetes Complications. 2003;17:153-9.

106. Ogata N, Imaizumi M, Nomura S, Shouzu A, Arichi M, Matsuoka M. Increased levels of platelet-derived microparticles in patients with diabetic retinopathy. Diabetes Res Clin Pract. 2005;68:193-201.

107. Sabatier F, Darmon P, Hugel B, Combes V, Sanmarco M, Velut JG, et al. Type 1 and type 2 diabetic patients display different patterns of cellular microparticles. Diabetes. 2002:51:2840-5.

108. Omoto S, Nomura S, Shouzu A, Nishikawa M, Fukuhara S, Iwasaka T. Detection of monocyte-derived microparticles in patients with type II diabetes mellitus. Diabetologia. 2002;45:550-5.

109. Nomura S, Kanazawa S, Fukuhara S. Effects of efonidipine on platelet and monocyte activation markers in hypertensive patients with and without type 2 diabetes mellitus. J Hum Hypertens. 2002;16:539-47.

110. Nomura S, Takahashi N, Inami N, Kajiura T, Yamada K, Nakamori H, et al. Probucol and ticlopidine: effect on platelet and monocyte activation markers in hyperlipidemic patients with and without type 2 diabetes. Atherosclerosis. 2004;174:329-35.

111. Nomura S, Shouzu A, Omoto S, Nishikawa M, Iwasaka T. Long-term treatment with nifedipine modulates procoagulant markers and C-C chemokine in hypertensive patients with type 2 diabetes mellitus. Thromb Res. 2005;115:277-85.

112. Nomura S, Shouzu A, Omoto S, Nishikawa M, Fukuhara S, Iwasaka T. Effects of valsartan on monocyte/endothelial cell activation markers and adiponectin in hypertensive patients with type 2 diabetes mellitus. Thromb Res. 2006;117:385-92.

113. Nomura S, Inami N, Kimura Y, Omoto S, Shouzu A, Nishikawa M, et al. Effect of nifedipine on adiponectin in hypertensive patients with type 2 diabetes mellitus. J Hum Hypertens. 2007;21:38-44.
114. Ogata N, Nomura S, Shouzu A, Imaizumi M, Arichi M, Matsumura M. Elevation of monocyte-derived microparticles in patients with diabetic retinopathy. Diabetes Res Clin Pract. 2006;73:241-8

115. Koga H, Sugiyama SD, Kugiyama K, Watanabe K, Fukushima H, Tanaka T, et al. Elevated levels of VE-cadherin-positive endothelial microparticles in patients with type 2 diabetes mellitus and coronary artery disease. J Am Coll Cardiol. 2005:45:1622-30

116. Levi M, Ten Cate H. Disseminated intravascular coagulations. N Engl J Med. 1999;341:586-92

117. Hatada T, Wada H, Nobori T, Okabayashi K, Maruyama K, Abe Y, et al. Plasma concentrations and importance of High Mobility Group Box protein in the prognosis of organ failure in patients with disseminated intravascular coagulation. Thromb Haemost. 2005;94:975-9.

118. Nomura S, Fujita S, Ozasa R, Nakanishi T, Miyaji M, Mori S, et al. Correlation between platelet activation markers and HMGB1 in DIC patients with hematologic malignancy. Platelets. 2011;22:396-7.

119. Delabrache $X$, Boisramé-Helms J, Asfar P, Berger A, Mootien Y, Lavigne T, et al. Microparticles are new biomarkers of septic shock-induced disseminated intravascular coagulopathy. Intensive Care Med. 2013;39:1695-703.

120. Hellum M, Øvstebø R, Brusletto BS, Berg JP, Brandtzaeg P, Henriksson CE. Microparticle-associated tissue factor activity correlates with plasma levels of bacterial lipopolysaccharides in meningococcal septic shock. Thromb Res. 2014;133:507-14

121. Nomura S, Kagawa H, Ozaki Y, Nagahama M, Yoshimura C, Fukuhara S. Relationship between platelet activation and cytokines in systemic inflammatory response syndrome patients with hematological malignancies. Thromb Res. 1999;95:205-13.

122. Nieuwland R, Berckmans RJ, McGregor S, Böing AN, Romijin FP, Westendorp $\mathrm{RG}$, et al. Cellular origin and procoagulant properties of microparticles in meningococcal sepsis. Blood. 2000;95:930-5.

123. Nomura S, Inami N, Kanazawa S, Iwasaka T, Fukuhara S. Elevation of platelet activation markers and chemokines during peripheral blood stem cell harvest with G-CSF. Stem Cells. 2004;22:696-703.

124. Nomura $S$, Ishii $K$, Inami N, Kimura $Y$, Uoshima N, Urase F, et al. $a_{4}$ integrinpositive microvesicles and SDF-1 in peripheral blood stem cell harvest. Bone Marrow Transplant. 2008;41:1071-2.

125. Nomura S, Ishii K, Inami N, Kimura Y, Uoshima N, Ishida H, et al. Evaluation of angiopoietin and cell-derived microparticles after stem cell transplantation. Biol Blood Marrow Transplant. 2008;14:766-74.

126. Nomura S, Inami N, Ozaki Y, Kagawa H, Fukuhara S. Significance of microparticles in progressive systemic sclerosis with interstitial pneumonia. Platelets. 2008;19:192-8.

127. Nomura S, Imamura A, Okuno M, Kamiyama Y, Fujimura $Y$, Ikeda $Y$, et al. Platelet-derived microparticles in patients with arteriosclerosis obliterans: enhancement of high shear-induced microparticle generation by cytokines. Thromb Res. 2000;98:257-68.

128. Nomura S, Inami N, Iwasaka T, Liu Y. Platelet activation marker, microparticles and soluble adhesion molecules are elevated in patients with atherosclerosis obliterans: therapeutic effects by cilostazol and potentiation by dipyridamole. Platelets. 2004;15:167-72

129. Nomura S, Shouzu Omoto S, Nishikawa M, Iwasaka T. 5-HT 2 receptor antagonist increases circulating adiponectin in patients with type 2 diabetes mellitus. Blood Coagul Fibrinolysis. 2005;16:423-8.

130. Baj-Kizyworzeka M, Majka M, Oratico D, Ratajczak J, Vilaire G, Kijowski J, et al. Platelet-derived microparticles stimulate proliferation, survival, adhesion, and chemotaxis of hematopoietic cells. Exp Hematol. 2002;30:450-9.

131. Nomura S, Kanazawa S, Inami N, Kamitsuji Y, Uoshima N, Ishida H, et al. Role of platelet-derived chemokines (RANTES and ENA-78) after stem cell transplantation. Transpl Immunol. 2006;15:247-53.

132. Nomura S, Ishii K, Inami N, Uoshima N, Ishida H, Yoshihara T, et al. Role of soluble tumor necrosis factor-related apoptosis-inducing ligand concentration after stem cell transplantation. Transpl Immunol. 2007;18:115-21.

133. Majka M, Kijowski J, Lesko E, Gozdzik J, Zupanska B, Ratajczak MZ. Evidence that platelet-derived microvesicles may transfer platelet-specific immunoreactive antigens to the surface of endothelial cells and CD34+ hematopoietic stem/progenitor cells - implication for the pathogenesis of immune thrombocytopenias. Folia Histochem Cytobiol. 2007;45:27-32.

134. Deregibus MC, Cantaluppi V, Calogero R, Lo lacono M, Tetta C, Biancone L, et al. Endothelial progenitor cell-derived microvesicles activate an angiogenic program in endothelial cells by a horizontal transfer of mRNA. Blood. 2007;110:2440-8. 
135. Janowska-Wieczorek A, Wysoczynski M, Kijowski J, Marquez-Curtis L, Machalinski B, Ratajczak J, et al. Microvesicles derived from activated platelets induce metastasis and angiogenesis in lung cancer. Int J Cancer. 2005;113:752-60.

136. Ratajczak J, Miekus K, Kucia M, Zhang J, Reca R, Dvorak P, et al. Embryonic stem cell-derived microvesicles reprogram hematopoietic progenitors: evidence for horizontal transfer of mRNA and protein delivery. Leukemia. 2006;20:847-56.

137. Kanazawa S, Nomura S, Kuwana M, Muramatsu M, Yamaguchi K, Fukuhara S. Monocyte-derived microparticles may be a sign of vascular complication in patients with lung cancer. Lung Cancer. 2003;39:145-9.

138. Janowska-Wieczorek A, Marquez-Curtis LA, Wysoczynski M, Ratajczak MZ. Enhancing effect of platelet-derived microvesicles on the invasive potential of breast cancer cells. Transfusion. 2006;46:1199-209.

139. Kalinkovich A, Tavor S, Avigdor A, Kahn J, Brill A, Petit I, et al. Functional CXCR4-expressing microparticles and SDF-1 correlate with circulating acute myelogenous leukemia cells. Cancer Res. 2006;66:11013-20.

140. Yu JL, May L, Lhotak V, Shahrzad S, Shirasawa S, Weitz Jl, et al. Oncogenic events regulate tissue factor expression in colorectal cancer cells: implications for tumor progression and angiogenesis. Blood. 2005;105:1734-41.

141. DelConde I, Bharwani LD, Dietzen DJ, Pendurthi U, Thiagarajan P, Lopez JA Microvesicle-associated tissue factor and Trousseau's syndrome. J Thromb Haemost. 2007;5:70-4.

142. Tesselaar ME, Romijn FP, Van Der Linden IK, Prins FA, Bertina RM, Osanto S. Microparticle-associated tissue factor activity: a link between cancer and thrombosis ? J Thromb Haemost. 2007;5:520-7.

143. Tilley RE, Holscher T, Belani R, Nieva J, Mackman N. Tissue factor activity is increased in a combined platelet and microparticle sample from cancer patients. Thromb Res. 2008;122:604-9.

144. Davila M, Amirkhosravi A, Coll E, Desai H, Robles L, Colon J, et al. Tissue factor-bearing microparticles derived from tumor cells: impact on coagulation activation. J Thromb Haemost. 2008;6:1517-24.

145. Meng Y, Kang S, Fishman DA. Lysophosphatidic acid stimulates Fas ligand microvesicles release from ovarian cancer cells. Cancer Immunol Immunother. 2005;54:807-14.

146. Kim JW, Wieckowski E, Taylor DD, Reichert TE, Watkins S, Whiteside TL. Fas ligand-positive membranous vesicles isolated from sera of patients with oral cancer induce apoptosis of activated T lymphocytes. Clin Cancer Res. 2005;11:1010-20

147. Huber V, Fais S, lero M, Lugini L, Canese P, Squarcina P, et al. Human colorectal cancer cells induce T-cell death through release of proapoptotic microvesicles: role in immune escape. Gastroenterology. 2005:128:1796-804.

148. Morel O, Ohlmann P, Epailly E, Backouboula B, Zobairi F, Jesel L, et al. Endothelial cell activation contributes to the release of procoagulant microparticles during acute cardiac allograft rejection. J Heart Lung Transplant. 2008;27:38-45.

149. Bakouboula B, Morel O, Faure A, Zobairi F, Jesel L, Trinh A, et al. Procoagulant membrane microparticles correlate with the severity of pulmonary arterial hypertension. Am J Respir Crit Care Med. 2008;177:536-43.

\section{Submit your next manuscript to BioMed Central and take full advantage of:}

- Convenient online submission

- Thorough peer review

- No space constraints or color figure charges

- Immediate publication on acceptance

- Inclusion in PubMed, CAS, Scopus and Google Scholar

- Research which is freely available for redistribution

Submit your manuscript at www.biomedcentral.com/submit
C Biomed Central 